\title{
Does mating interfere in the biological characteristics of a population of Trichogramma pretiosum?
}

\author{
DIRCEU PRATISSOLI, THIAGO G. KLOSS, FERNANDO D. ZINGER, \\ JOSÉ R. DE CARVALHO, ULYSSES R. VIANNA and JOÃO P.P. PAES
}

\author{
Universidade Federal do Espírito Santo, Centro de Ciências Agrárias, Caixa Postal 16, 29500-000 Alegre, ES, Brasil
}

Manuscript received on March 5, 2012; accepted for publication on April 3, 2013

\begin{abstract}
Trichogramma spp. are parasitoids used in the regulation of insect populations that can cause economic damage. In order to ensure good performance, understanding some of their biological characteristics is essential. The objective of this study is to evaluate whether mating interferes with the biological characteristics of a population of Trichogramma pretiosum collected in the field. In all experiments, groups of mated and unmated females were used. We also verified any interference from mating on the biological characteristics of the offspring. We found that mating can alter the parasitism and longevity of genitor females, in addition to changing longevity among the descendants, but once parasitized, the eggs develop normally, showing similar emergence percentage and number of offspring as those from unmated females. In addition, we verified that the population of T. pretiosum collected in the field presented individuals with reproductive thelytokous and arrhenotokous characteristics. This fact highlights the importance of careful investigation on the reproduction mode of populations collected in the field, thus avoiding problems in the effective management of insect populations.
\end{abstract}

Key words: Egg parasitoids, mating, telytokous, arrhenotokous.

\section{INTRODUCTION}

Parasitoids are key species in the regulation of insect populations (Querino et al. 2010). Several species of parasitoids are used for pest management in the field, one example being the genus Trichogramma Westwood, 1833 (Hymenoptera: Trichogrammatidae), which has been reported parasitizing more than 200 species of insects that cause economic damage to crops, mainly of the order Lepidoptera (Pratissoli et al. 2004, Delpuech et al. 2010, Davies et al. 2011).

The most common reproduction mode in Trichogramma, and in Hymenoptera in general,

Correspondence to: Thiago Gechel Kloss

E-mail: thiagokloss@yahoo.com.br is arrhenotoky, that is, fertilized eggs that produce diploid females and unfertilized eggs that produce haploid males. Another less common mode is thelytoky, characterized by the production of diploid females from fertilized and unfertilized eggs (Pintureau et al. 1999). In Trichogramma, there are two forms of thelytoky: a reversible one (associated with infections caused by bacteria of the genus Wolbachia) and a non-reversible form (Beserra et al. 2003a, Russell and Stouthamer 2010). Moreover, individuals with thelytokous and arrhenotokous characteristics may be present in the same population (Stouthamer 1993, Wang and Smith 1996). 
DIRCEU PRATISSOLI et al

In arrhenotokous Trichogramma species, mating is an important factor to consider for the successful use of these species in the field, since unfertilized eggs produce male individuals (Pratissoli et al. 2009, Farrokhi et al. 2010), which can compromise the maintenance of the parasitoid in the field. On the other hand, mating in thelytokous species is not essential to ensure a large number of female descendants, since both fertilized and unfertilized eggs will produce females (Hohmann et al. 2002). Thus, field releases of thelytokous populations can be more efficient when compared to arrhenotokous populations (Stouthamer 1993).

Although mating is not taken into consideration in field releases of Trichogramma species, the energy expenditure can alter the biology of this parasitoid, affecting its ability to control insect populations. Therefore, this study aims to determine whether mating can interfere in the biological characteristics of Trichogramma pretiosum Riley, 1879, thus reducing the efficiency of its desirable characteristics.

\section{MATERIALS AND METHODS}

FIELD COLLECTION OF Trichogramma

Tomato fruits containing parasitized eggs of Neoleucinodes elegantalis (Guenée, 1854) (Lepidoptera: Crambidae) were collected from commercial tomato crops in the municipality of Alegre, Espírito Santo, Brazil (41²9'21"W $20^{\circ} 45^{\prime} 8^{\prime}$ 'S). The eggs were removed from the tomato fruits at the Laboratory of Entomology of the Núcleo de Desenvolvimento Científico e Tecnológico em Manejo Fitossanitário de Pragas e Doenças of the Universidade Federal do Espírito Santo (NUDEMAFI) and individually transferred into glass tubes $(4 \times 0.5 \mathrm{~cm})$ covered with PVC plastic wrap and maintained in climatic chambers at a temperature of $25 \pm 1{ }^{\circ} \mathrm{C}$, RH of $70 \pm 10 \%$ and $14 \mathrm{~h}$ photophase, until emergence of the parasitoids. The identification of the parasitoids was based on Querino and Zucchi (2011).
EFFECT OF MATING ON THE BIOLOGICAL CHARACTERISTICS OF T. pretiosum

After sexing of the emerged parasitoids, 13 virgin females and 7 couples were individualized in glass tubes $(4 \times 1 \mathrm{~cm})$ containing a droplet of honey as a food resource for the adults. The tubes were kept in a climatic chamber similar to the one described above. Twenty-five eggs of the host Anagasta kuehniella (Zeller, 1879) (Lepidoptera: Pyralidae) stuck to paper cards $(2 \times 0.5 \mathrm{~cm})$ with Arabic gum (10\%) were offered daily. The eggs were less than 12 hours old and turned unviable by previous exposure to a germicidal lamp. This process continued until female death when they were transferred to other tubes $(4 \times 1 \mathrm{~cm})$ to wait for the emergence of the offspring which were also kept in a climatic chamber. The males were left in with coupled females till their death. During the experiment we evaluated the longevity of mated and unmated parasitoid females, the percentage of eggs parasitized, the sex ratio, the percentage of emergence and the number of parasitoids per egg.

EFFECT OF MATING ON THE BIOLOGICAL CHARACTERISTICS OF THE OFFSPRING

Twenty females were individualized, ten from unmated individuals and ten from mated individuals. Similar to the procedure used in the experiment with the generation collected in the field, the females were individualized in glass tubes $(4 \times 1 \mathrm{~cm})$ containing a droplet of honey for food. These were also placed in a climatic chamber as in the previous experiment. Twenty-five eggs of the host $A$. kuehniella stuck to paper cards $(2 \times 0.5 \mathrm{~cm})$ with Arabic gum $(10 \%)$ were offered daily, until the death of the parasitoids. The eggs were less than 12 hours old and turned unviable by previously exposing them to a germicidal lamp. Later, the cards submitted to parasitism were also transferred to other tubes to await the emergence of the offspring. For this experiment the parameters evaluated were the same as the ones described above. 


\section{STATISTICAL ANALYSIS}

The experimental design was completely randomized and we used the t-test for independent means at $5 \%$ probability to compare the biological characteristics of mated and unmated females and among the female offspring. We performed all statistical analyzes using the R program.

\section{RESULTS}

The mating affected the parasitism ability of the parasitoid $(\mathrm{t}=2.69 ; \mathrm{df}=18 ; \mathrm{P}=0.014)$, and the mated females exhibited a lower percentage of parasitism in relation to unmated females (Table I). Moreover, mated females lived less in relation to unmated females $(\mathrm{t}=2.22 ; \mathrm{df}=18 ; \mathrm{P}=0.039)$ (Table I). However, the presence of males did not alter the number of individuals per egg $(t=-1.60$; $\mathrm{df}=18 ; \mathrm{P}=0.126)$, the emergence percentage of the offspring $(\mathrm{t}=0.32 ; \mathrm{df}=7.72 ; \mathrm{P}=0.757)$ or the sex ratio $(\mathrm{t}=-1.47 ; \mathrm{df}=12 ; \mathrm{P}=0.165)$ (Table $\mathrm{I})$.

\section{TABLE I}

Interference of mating on the biological characteristic of the population of Trichogramma pretiosum (Hymenoptera: Trichogrammatidae) collected in the field $\left(25 \pm 1{ }^{\circ} \mathrm{C}\right.$, RH of $70 \pm 10 \%$ and $14-h$ photophase). Means \pm SE followed by the same letter in the line are statistically similar according to the t-test $($ sig. $=0.05)$.

\begin{tabular}{ccc}
\hline $\begin{array}{c}\text { Biological } \\
\text { Characteristics }\end{array}$ & \multicolumn{2}{c}{ Treatments } \\
\hline Mated females & $\begin{array}{c}\text { Unmated } \\
\text { females }\end{array}$ \\
\cline { 2 - 3 } Parasitism (\%) & $22.31 \pm 2.78 \mathrm{~b}$ & $34.61 \pm 2.97 \mathrm{a}$ \\
Individuals per egg & $1.00 \pm 0.002 \mathrm{a}$ & $1.01 \pm 0.003 \mathrm{a}$ \\
Emergence (\%) & $94.57 \pm 2.43 \mathrm{a}$ & $95.40 \pm 0.91 \mathrm{a}$ \\
Sex ratio & $1.00 \pm 0.00 \mathrm{a}$ & $0.84 \pm 0.01 \quad \mathrm{a}$ \\
Longevity (Days) & $8.85 \pm 1.23 \mathrm{~b}$ & $11.46 \pm 0.55 \mathrm{a}$ \\
\hline
\end{tabular}

Among the offspring, mating did not affect parasitism in relation to unmated females $(t=$ -0.008; df $=18 ; \mathrm{P}=0.993)$. However, longevity was altered $(\mathrm{t}=2.32 ; \mathrm{df}=18 ; \mathrm{P}=0.031)$, since female offspring of unmated females lived longer compared to the others (Table II).
Similar to the results found for the generation collected in the field, the biological characteristics, number of individuals per egg $(\mathrm{t}=-0.84 ; \mathrm{df}=11.03$; $\mathrm{P}=0.417)$, sex ratio $(\mathrm{t}=0 ; \mathrm{df}=0 ; \mathrm{P}=1)$ and emergence percentage of the offspring $(\mathrm{t}=-1.88 ; \mathrm{df}=18 ; \mathrm{P}=$ $0.075)$ were not affected by mating (Table II).

\section{TABLE II}

Interference of mating on the biological characteristic of the offspring population of Trichogramma pretiosum

(Hymenoptera: Trichogrammatidae), obtained in the laboratory $\left(25 \pm 1^{\circ} \mathrm{C}, \mathrm{RH}\right.$ of $70 \pm 10 \%$ and 14 -h photophase). Means \pm SE followed by the same letter in the line are statistically similar according to the t-test $($ sig. $=0.05)$.

\begin{tabular}{ccc}
\hline $\begin{array}{c}\text { Biological } \\
\text { Characteristics }\end{array}$ & \multicolumn{2}{c}{ Treatments } \\
\hline & $\begin{array}{c}\text { Descendents of } \\
\text { mated females }\end{array}$ & $\begin{array}{c}\text { Descendents of } \\
\text { unmated } \\
\text { females }\end{array}$ \\
\cline { 2 - 3 } Parasitism (\%) & $29.67 \pm 2.36 \mathrm{a}$ & $29.65 \pm 1.64 \mathrm{a}$ \\
Individuals per egg & $1.02 \pm 0.01 \quad \mathrm{a}$ & $1.01 \pm 0.006 \mathrm{a}$ \\
Emergence (\%) & $94.76 \pm 1.21 \mathrm{a}$ & $91.59 \pm 1.14 \mathrm{a}$ \\
Sex ratio & $1.00 \pm 0.0 \quad \mathrm{a}$ & $1.00 \pm 0.0 \quad \mathrm{a}$ \\
Longevity (Days) & $11.33 \pm 1.14 \mathrm{~b}$ & $14.27 \pm 0.66 \mathrm{a}$ \\
\hline
\end{tabular}

\section{DISCUSSION}

Reduction in parasitism and longevity of the mated females from the generation collected in the field may reflect the impact that the energy cost from mating exerts on these parasitoids. Parasitism and longevity may interfere with the success of the populations in the field (Thomson and Hoffmann 2002, Bessera et al. 2003b, Pratissoli et al. 2009), and their reduction may also be caused by other conditions such as food restriction (Hegazi et al. 2000, Murta et al. 2008). However, in this study, the food resources were not restricted to females, emphasizing the effect of mating on the biological characteristics of this egg parasitoid.

The low number of parasitoids produced per host egg which was, on average, one parasitoid, was not affected by mating. In Trichogramma the number of emerged parasitoids is related to egg volume (Vianna et al. 2011) and low values, 
as reported in this study, may represent a major advantage in the development of Trichogramma species, since a larger amount of nutrients will be available for assimilation and development of the parasitoid, thereby producing the largest and most competitive individuals (Bessera et al. 2003b).

The percentage of emerged individuals also did not differ between treatments and was greater than $90 \%$, as have been reported in other studies (Dias et al. 2008, Pratissoli et al. 2009).

The fact that the population studied is predominantly thelytokous resulted in the absence of any variation caused by mating on the sex ratio, because both fertilized and unfertilized eggs can only generate females in these populations (Farrokhi et al. 2010). The predominance of this characteristic in the population of $T$. pretiosum is probably associated with the presence of bacteria of the genus Wolbachia (Stouthamer et al. 1990, Cônsoli and Parra 2002, Farrokhi et al. 2010).

Nevertheless, despite the predominance of the thelytokous form of reproduction, individuals with arrhenotokous reproductive characteristics were found in the population collected in the field, which is likely to occur in any population of Trichogramma (Stouthamer 1993). This confirmation was verified through the exclusive presence of males, in some repetitions cosisting of unmated (arrhenotokous) females (Table I). However, the presence of arrhenotokous females in the population was low (two females/repetition).

This result highlights the need to assess possible negative effects generated by this population condition. Although mating is not required for thelytokous populations to produce female offspring, it should be noted that mating may occur through the presence of arrhenotokous males in the population. Because mating can affect the efficiency of females in the field, we suggest that when rearing these parasitoids in the laboratory, careful verification of the presence of arrhenotokous individuals in thelytokous populations is necessary.
The use of populations that reproduce by thelytoky is desirable in relation to some aspects of arrhenotokous populations (Stouthamer 1993, Farrokhi et al. 2010). For example, thelytokous populations of Trichogramma have a high rate of population growth in the field; low-cost mass production because there is no waste of host for the production of males; rapid establishment in the field, because mating is not required to produce female offspring; and favorable use at low host densities, because in these conditions the encounter between sexual partners is detrimental and since thelytokous populations do not need to mate, their use is favored (Stouthamer 1993).

However, thelytokous populations have lower fertility and are not suitable for use when insect hosts in the field occur at high densities (Wang and Smith 1996), thus indicating that the choice of population type of Trichogramma used in the management of insects in the field, depends, among other things, on the level of infestation of these populations.

Aspects related to cultivation are also important when choosing the form of reproduction to be used. In annual crops, arrhenotokous populations can be adopted, since the maintenance of populations of Trichogramma in these cultures is not particularly needed (Pratissoli et al. 2009). This population in the field may be compromised in the presence of a large number of male offspring from unmated arrhenotokous females. However, there is no restriction on the use of thelytokous populations for annual crops, although they are not strictly necessary. Conversely, for perennial crops thelytokous populations are more appropriate, because the maintenance of the population of Trichogramma in the field is a relevant factor.

As expected, when verifying the effect caused by mating on offspring, no change in most biological characteristics was evident because all were produced under controlled conditions and did not mate. However, the longevity differed between them and this difference may be due to the fact that mating produced more genetically heterogeneous 
descendants, since there was an exchange of gametes. However, detailed studies are needed to confirm the relationship between mating and longevity of the offspring.

\section{ACKNOWLEDGMENTS}

We thank the Conselho de Aperfeiçoamento de Pessoal de Nível Superior (CAPES) and the Conselho Nacional de Desenvolvimento Científico e Tecnológico (CNPq).

\section{RESUMO}

Trichogramma spp. são parasitoides utilizados na regulação de populações de insetos que podem causar danos econômicos. Para que esses tenham bom desempenho é essencial o conhecimento de algumas de suas características biológicas. O objetivo deste trabalho foi avaliar se o acasalamento interfere nas características biológicas de uma população de Trichogramma pretiosum coletada em campo. Em todos os experimentos, grupos de fềmeas acasaladas e não acasaladas foram utilizados. Além disso, foi verificada a interferência do acasalamento nas características biológicas dos descendentes. Foi constatado que o acasalamento é capaz de alterar o parasitismo e a longevidade das fêmeas genitoras, além de alterar a longevidade entre os descendentes, porém, uma vez parasitados, os ovos se desenvolvem normalmente, apresentando viabilidade e número de descendentes similares aos das fêmeas não acasaladas. Verificamos ainda, que a população de T. pretiosum coletada em campo apresentou indivíduos com características reprodutivas telítocas e arrenótocas. Esse fato ressalta a importância de investigações cuidadosas sobre o modo de reprodução das populações coletadas em campo, evitando assim problemas de eficiência no manejo de populações de insetos.

Palavras-chave: parasitoides de ovos, acasalamento, telítoca, arrenótoca.

\section{REFERENCES}

BESERRA EB, DiAs CTS AND PARRA JRP. 2003b. Características biológicas de linhagens de Trichogramma pretiosum desenvolvidas em ovos de Spodoptera frugiperda. Acta Sci Agron 25: 479-483.
BESERRA EB, QUERINO RB AND PARRA JRP. 2003a. Ocorrência de ginandromorfismo em Trichogramma pretiosum Riley (Hymenoptera: Trichogrammatidae). Neotrop Entomol 32: 507-509.

CÔNSOLI FL AND PARRA JRP. 2002. Criação in vitro de Parasitóides e Predadores. In: PARRA JRP, BOTELHO PSM, CORREAA-FERREIRA BS AND BENTO JMS (Eds), Controle Biológico no Brasil: Parasitóides e Predadores, São Paulo: Manole, p. 239-262.

DAVIES AP, CARR CM, SCHOLZ BCG AND ZALUCKI MP. 2011. Using Trichogramma Westwood (Hymenoptera: Trichogrammatidae) for insect pest biological control in cotton crops: an Australian perspective. Aust J Entomol 50: 424-440.

Delpuech JM, Dupont C AND Allemand R. 2010. Decrease in Fecundity Induced by Interspecific Mating Between Two Trichogramma Parasitoid Species. J Econ Entomol 103: 308-313.

DIAS NS, PARRA JRP AND DIAS CTS. 2008. Tabela de vida de fertilidade de três espécies neotropicais de Trichogrammatidae em ovos de hospedeiros alternativos como critério de seleção hospedeira. Rev Bras Entomol 54: 120-124.

FARrokhI S, AShouri A, ShIRAZI J, AllahVARI H AND HuIGENS ME. 2010. A comparative study on the functional response of Wolbachia-infected and uninfected forms of the parasitoid wasp Trichogramma brassicae. J Insect Sci 10: $1-11$.

Hegazi EM, Khafagi WE AND Hassan SA. 2000. Studies on three species of Trichogramma. I. Foraging behavior for food or hosts. J Appl Ent 124: 145-149.

HohmanN CL, LUCK RF AND StOUthamer R. 2002. Effect of Wolbachia on the survival and reproduction of Trichogramma kaykai Pinto and Stouthamer (Hymenoptera: Trichogrammatidae). Neotrop Entomol 30: 607-612.

Murta AF, Ker FTO, Costa DB, EsPírito-SANTO MM AND FARIA ML. 2008. Efeitos de remanescentes de Mata Atlântica no controle biológico de Euselasia apisaon (Dahman) (Lepidoptera: Riodinidae) por Trichogramma maxacalii (Voegelé e Pointel) (Hymenoptera: Trichogrammatidae). Neotrop Entomol 37: 229-232.

Pintureau B, Chapelle L and Delobel B. 1999. Effects of repeated thermic and antibiotic treatments on a Trichogramma (Hym., Trichogrammatidae) symbiont. J Appl Ent 123: 473-483.

Pratissoli D, Holtz AM, Gonçalves JR, VianNa UR AND BELLINI LL. 2004. Efeito da ausência de hospedeiro e de alimento sobre aspectos biológicos de Trichogramma pretiosum Riley (Hymenoptera: Trichogrammatidae). Act Sci 26: 281-286.

Pratissoli D, Oliveira HN, Polanczyk RA, Holtz AM, Bueno RCOF, Bueno AF AND GONÇALVEZ JR. 2009. Adult Feeding and Mating Effects on the Biological Potential and Parasitism of Trichogramma pretiosum and T. acacioi (Hym.: Trichogrammatidae). Braz Arch Biol Technol 52: 1057-1062. 
QUERINO RB AND ZUCCHI RA. 2011. Guia de identificação de Trichogramma para o Brasil, $1^{\text {a }}$ ed., Brasília: Embrapa Informação Tecnológica, 113 p.

QUERINO RB, ZUCCHI RA AND PINTO JD. 2010. Systematics of the Trichogrammatidae (Hymenoptera: Chalcidoidea) with a Focus on the Genera Attacking Lepidoptera. In: CÔNSOLI FL, PARRA JRP AND ZUCCHI RA (Eds), Egg Parasitoids in Agroecosystems with Emphasis on Trichogramma, Piracicaba: Springer, p. 191-218.

RUSSELl JE AND STOUTHAMER R. 2010. Sex Ratio Modulators of Egg Parasitoids. In: CÔNSOLI FL, PARRA JRP AND ZUCCHI RA (Eds), Egg Parasitoids in Agroecosystems with Emphasis on Trichogramma, Piracicaba: Springer, $\mathrm{p}$ $167-190$

StOUthamer R. 1993. The use of sexual versus asexual wasps in biological control. Entomophaga 38: 3-6.

STOUTHAMER R, LUCK RF AND HAMILTON WD. 1990 Antibiotics cause parthenogenetic Trichogramma (Hymenoptera/Trichogrammatidae) to revert to sex. Proc Nat Acad Sci 87: 2224-2427.
THOMSON LJ AND HOFFMANN AA. 2002. Laboratory fecundity as predictor of field success in Trichogramma carverae (Hymenoptera: Trichogrammatidae). J Econ Entom 95: 912-917.

VianNa UR, Pratissoli D, ZANUNCIO JC, DE AlENCAR JRCC AND ZINGER FD. 2011. Espécies e/ou linhagens de Trichogramma spp. (Hymenoptera: Trichogrammatidae) para o controle de Anticarsia gemmatalis (Lepidoptera: Noctuidae). Arq Inst Biol 78: 81-87.

WANG Z AND SMITH SM. 1996. Phenotypic differences between thelytokous and arrhenotokous Trichogramma minutum from Zeiraphera Canadensis. Ent Exp Appl 78: 315-323. 